\title{
The Improvement of Zinc Bioavailability in Fermented Soybean Meal in Growing Pigs
}

\author{
Tohru MATSUI, Hisashi SUSAKI, Akira TAMURA, \\ Hideo YANO, Takashi NAKAJIMA ${ }^{12}$, Motohiro MATSUDA ${ }^{2)}$ \\ and Fumiko YANO ${ }^{3}$ \\ Graduate School of Agriculture, Kyoto University, Sakyo-ku, \\ Kyoto-shi 606-8502 \\ 1) School of Environmental Science, The University of Shiga Prefecture, \\ Hikone-shi 522-8533 \\ 2). Wakayama Research Institute of Animal Production, Susami-machi, \\ Wakayama-ken 649-3141 \\ 3) Faculty of Biology-Oriented Science, Kinki University, Uchita-machi, \\ Wakayama-ken 649-6493
}

(Received November 25, 1997)

\begin{abstract}
The efficacy of fermentation on zinc bioavailability in soybean meal was studied in growing pigs. Fifteen growing pigs, average initial body weight and age of $20 \mathrm{~kg}$ and 8 weeks, were fed a soybean meal based-diet (SBM diet), a soybean meal based diet added with monosodium phosphate at $7,5 \mathrm{~g} / \mathrm{kg}$ of air dry matter (SBM $+\mathrm{P}$ diet), or a fermented soybean meal-based diet (FSBM diet) for 30 days. Zinc concentration in each diet was almost the lower limit of its requirement in the growing pigs. The FSBM group showed higher zinc concentrations in the femoral cortex and serum than did the other groups. These results suggested that fermentation of soybean meal improved zinc bioavailability in growing pigs.
\end{abstract}

Anim. Sci. Technol. (Jpn.) 69 (6) : 589-591, 1998

Key words : Phytate, Fermentation, Zinc bioavailability, Pigs, Soybean meal

Soybean meal is a basic protein source in swine feeds. However, the bioavailability of zinc is not high in soybean products because phytate in soybean products strongly interferes with zinc absorption ${ }^{7,8)}$. Smith et al. ${ }^{7}$ reported that growing pigs did not show zinc deficiency when the animals were given milk protein-based diets containing 6 to $18 \mathrm{mg} / \mathrm{kg}$ of zinc but a soybean meal-based diet containing $22 \mathrm{mg} / \mathrm{kg}$ of zinc induced zinc deficiency. National Research Council showed that zinc requirement was $60 \mathrm{mg} / \mathrm{kg}$ diet in growing pigs weighing between 20 to $50 \mathrm{~kg}$ and fed a corn-soybean meal diet $^{6)}$.

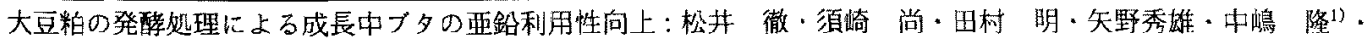

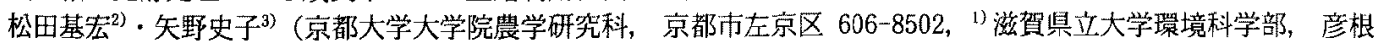
市 522-8533， ${ }^{2}$ 和歌山県畜産試験場, 和歌山県すさみ町 649-3141， ${ }^{3)}$ 近畿大学生物理工学部, 和歌山県打田町 649-6493) 
We previously reported that fermentation with Aspergillus usamii almost completely degraded phytate in soybean meal without adversely affecting crude protein content and amino acid composition ${ }^{4)}$. Furthermore, our preliminary study using rats showed that fermentation of soybean meal improved zinc bioavailability through dephytinization ${ }^{3)}$. The present experiment was conducted to determine whether fermentation of soybean meal improve zinc bioavailability in growing pigs.

\section{Materials and Methods}

Commercial soybean meal was fermented using Aspergillus usamii according to the method described previously ${ }^{4)}$. Fifteen Landrace barrows, average initial body weight and age of $20 \mathrm{~kg}$ and 8 weeks, were divided into three groups of 5 pigs each and each group was housed in a pen and fed a soybean meal-based diet (SBM diet), a soybean meal-based diet added with monosodium phosphate at $7.5 \mathrm{~g} / \mathrm{kg}$ of air dry matter (SBM+P diet), or a fermented soybean meal-based diet (FSBM diet). Each diet consisted mainly of $76 \%$ corn and $20 \%$ SBM or FSBM (air dry matter basis). Zinc was supplied to the diets at $40 \mathrm{mg} / \mathrm{kg}$ of air dry matter as zinc carbonate. The pigs were given free access to diets and water for 30 days. At the end of the feeding trial, the pigs were stunned electrically and bled. Blood, left femur and liver were collected. The femoral cortex was cleaned of adherent tissues, dried $\left(100^{\circ} \mathrm{C}\right.$ for $\left.24 \mathrm{~h}\right)$ and weighed. Zinc concentration was measured in the diets, serum, liver and femoral cortex using an atomic absorption spectrophotometer (AA-6600F, Shimadzu, Kyoto, Japan) after digestion with nitric acid and perchloric acid. Dietary phytate-phosphorus content was measured according to the method of the Association of Official Analytical Chemists ${ }^{1)}$. Phosphorus concentration in the diets were determined by Gomori's method $^{2)}$. The nonphytate-phosphorus content was calculated from the contents of total phosphorus and phytate-phosphorus.

All data were subjected to one-way analysis of variance using the General Linear Model procedure of Statistical Analysis System ${ }^{6)}$ at the probability level of $\mathrm{P}<0.05$. Treatment differences were distinguished using a $t$-test where the dietary effects were significant.

\section{Results and Discussion}

Zinc concentrations were 66,68 and $70 \mathrm{mg} / \mathrm{kg}$ of air dry matter in the SBM, FSBM and SBM+ $P$ diets, respectively. The requirements of zinc was $60 \mathrm{mg} / \mathrm{kg}$ diet in pigs weighing between 20 to $50 \mathrm{~kg}^{5}$. The dietary zinc concentrations were considered to be almost the lower limit of its requirement in the pigs. Dietary nonphytate-phosphorus concentration was 2.9 $\mathrm{g} / \mathrm{kg}$ of air dry matter in the FSBM and $3.6 \mathrm{~g} /$ $\mathrm{kg}$ of air dry matter in the SBM $+\mathrm{P}$ diets. The diets of FSBM and SBM $+P$ were considered to contain a sufficient amount of available phosphorus for these pigs $\left(2.3 \mathrm{~g} / \mathrm{kg} \operatorname{diet}^{5)}\right)$. The pigs fed the SBM diet were possibly phosphorus deficient because nonphytate-phosphorus contained only $2.1 \mathrm{~g} / \mathrm{kg}$ of air dry matter in this diet. However, the daily gain did not differ among the groups : daily gains were $0.65 \pm 0.05$, $0.64 \pm 0.05$ and $0.68 \pm 0.04 \mathrm{~kg}$ in the SBM, FSBM and $\mathrm{SBM}+\mathrm{P}$ groups, respectively. Therefore, it was likely that the SBM group had moderate phosphorus-deficiency which did not affect the performance.

The FSBM group showed significantly $(\mathrm{P}<$ 0.05 ) higher zinc concentrations in the femoral cortex and serum than the other groups (Table 1). The zinc concentration of the liver was also significantly $(\mathrm{P}<0.05)$ higher in the FSBM group than in the SBM $+\mathrm{P}$ group and tended to be higher in the FSBM group than in the SBM group $(\mathrm{P}<0.08)$. The lower concentration of zinc in the femur of the SBM group might be partly due to phosphorus deficiency because phosphorus deficiency considerably suppressed bone mineralization. However, the zinc concentrations of serum and liver were 
Fermented Soybean Meal and Zinc

Table 1. Zinc concentrations in femoral cortex, liver and serum of growing pigs fed soybean meal or fermented soybean meal

\begin{tabular}{lccc}
\hline \hline & $\begin{array}{c}\text { Femur } \\
(\mathrm{mg} / \mathrm{kg} \text { dry weight })\end{array}$ & $\begin{array}{c}\text { Liver } \\
(\mathrm{mg} / \mathrm{kg} \text { dry weight })\end{array}$ & $\begin{array}{l}\text { Serum } \\
(\mathrm{mg} / l)\end{array}$ \\
\hline SBM & $126.4 \pm 2.6^{*}$ & $175.3 \pm 10.8$ & $0.84 \pm 0.05^{*}$ \\
SBM +P & $115.5 \pm 7.0^{*}$ & $161.4 \pm 3.3^{*}$ & $0.71 \pm 0.05^{*}$ \\
FSBM & $144.1 \pm 6.5$ & $238.1 \pm 28.2$ & $1.03 \pm 0.04$ \\
\hline
\end{tabular}

Values are means \pm standard errors for 5 pigs.

*; Significantly $(\mathrm{P}<0.05)$ different from the FSBM group.

SBM ; Pigs fed the soybean meal diet.

$\mathrm{SBM}+\mathrm{P}$; Pigs fed the soybean meal diet added with monosodium phosphate at 7.5

$\mathrm{g} / \mathrm{kg}$ of air dry matter.

FSBM ; Pigs fed the fermented soybean meal diet.

also lower in the SBM group than in the FSBM group. Furthermore, phosphorus repletion had no effect on the lower levels of zinc in the tissues and serum. These results suggested that fermentation of soybean meal improved zinc bioavailability in growing pigs, which was in agreement with our previous report showing that dephytinization of soybean meal by fermentation improved zinc bioavailability in rats $^{3)}$. This experiment did not clarify how much zinc should be supplied in a FSBM-based diet. However, pigs fed a FSBM-based diet required lesser dietary zinc than did pigs fed a SBM-based diet and the amount of zinc supplementation could be reduced. Consequently, zinc content in manure is probably decreased as well. Zinc in the manure is a possible pollutant of arable land when the manure is applied there. The substitution of FSBM for SBM can alleviate this zinc pollution problem.

\section{Acknowledgements}

This work was partly supported by a Grantin-Aid (No. 09556062) from the Ministry of Education, Science and Culture of Japan. Fermented soybean meal was supplied by Minoru Takebe (Nichimo Co., Tokyo, Japan).

\section{References}

1) Association of Official Analytical Chemists. Official methods of analysis, 15 th cdn., vol. 1. 800-801. AOAC. Washington, DC. 1990.

2) Gomori G. A modification of the colorimetric phosphorus determination for use with the photoelectric colorimeter. J. Lab. Clin. Med., $27: 955-960.1942$.

3) Hirabayashi M, Matsui T, Yano H. Fermentation of soybean meal with Aspergillus usamii improves zinc availability in rat. Biol. Trace Elem. Res., 61 : 227-234. 1998.

4) Ilyas A, Hirabayashi M, Matsui $T$, Yano $H$, Yano $F$, Kikushima T, Takebe M, Hayakawa $K$. A note on the removal of phytate in soybean meal using Aspergillus usamii. Asian-Australasian J. Anim. Sci., 8 : 135-138. 1995.

5) National Research Council, Nutrient Requirements of Swine. Ninth revised edition. National Academy Press. Washington, DC. 1988.

6) SAS Institute. SAS User's Guide : Statistics, Version 5, SAS Institute Inc., Cray, NC. 1985.

7) Smith WH, Plumlee MP, Beeson WM. Effect of source of protein on zinc requirement of the growing pig. J. Anim. Sci., 21 : 399-405. 1962.

8) Zhou JR, Fordyce EJ, Raboy V, Dickinson DB, Wong MS, Burns RA, Erdman JW Jr. Reduction of phytic acid in soybean products improves zinc bioavailability in rats. J. Nutr., 122 : 2466-2473. 1992. 